\title{
NILAI-NILAI DALAM AKTUALISASI PENINGKATAN KARAKTER KEPEDULIAN LINGKUNGAN MAHASISWA
}

\author{
La Ode Nursalam', Eko Harianto3, Muhammad Hasan³, Andri Estining Sejati ${ }^{4}$ \\ 'Program Studi Pendidikan Geografi, Universitas Halu Oleo \\ Anduonohu, Kendari \\ 2Program Studi Agrobisnis, Universitas Terbuka Kendari \\ Anduonohu, Kendari \\ 3BBPK Makassar \\ Antang, Makassar
}

4Program Studi Pendidikan Geografi, Universitas Sembilanbelas November Kolaka

Jl. Pemuda No. 399 Kolaka

Email corresponding: laodenursalam@ymail.com

\begin{abstract}
The basic values of the State Civil Apparatus (ASN) consist of accountability, nationalism, public ethics, quality commitment, and anti-corruption. The position and role of ASN in the Republic of Indonesia consists of ASN management, the Whole of Government and Public Services. The basic values, roles, and position must be reflected in the issue of solving activities in the basic training activities of the Ministry of Research, Technology and Higher Education. This type of research is a pre-experimental paper with the subject of Udergraduate Geography Education 2016 class. Actualization was carried out from 16 August to 20 November 2018 at USN Kolaka. Activities on campus include: 1) carrying out environmental awareness counseling for students 2) implementing the environmental care integrity pact. 3) GIS training on environmental studies. Off campus activities include: 1) planting trees in the campus environment of USN Kolaka, 2) cleaning the gutters in the campus environment of USN Kolaka, 3) counseling and outreach activities to the community are adapted into environmental awareness counseling by students and lecturers to students in other majors (Mathematics Education). The research instruments were self evaluation, pretest and posttest. Self evaluation data were analyzed descriptively. While the pretest and posttest data were analyzed using parametric inferential statistics through one sample t-test with the help of SPSS 16.0 for Windows. The results of data analysis showed that there was an influence of Basic Training on the characters of environmental awareness of students with the significance value of testing one sample t-test with the help of SPSS 16.0 for Windows of 0,000. All activities nuanced basic values, roles and positions of ASN in the Homeland.
\end{abstract}

Keywords: basic training, character, environment awareness

\begin{abstract}
Abstrak
Nilai-nilai dasar Aparatur Sipil Negara (ASN) terdiri dari akuntabilitas, nasionalisme, etika publik, komitmen mutu, dan anti korupsi. Kedudukan dan peran ASN dalam NKRI terdiri dari manajemen ASN, Whole of Government dan Pelayanan Publik. Nilai dasar, peran, dan kedudukan tersebut wajib tercermin dalam kegiatan pemecahan isu pada kegiatan pelatihan dasar Kementristek Dikti. Jenis penelitian makalah adalah pre eksperimen dengan subjek mahasiswa S1 Pendidikan Geografi Kelas 2016. Aktualisasi dilakukan dari 16 Agustus hingga 20 November 2018 di USN Kolaka. Kegiatan on campus meliputi: 1) melaksanakan penyuluhan peduli lingkungan kepada mahasiswa 2) penerapan pakta integritas peduli lingkungan. 3) Pelatihan SIG kajian lingkungan. Kegiatan off campus meliputi: 1) penanaman Pohon di lingkungan kampus USN Kolaka, 2) Pembersihan Selokan di lingkungan kampus USN Kolaka, 3) kegiatan penyuluhan dan sosialisasi ke masyarakat diadaptasi menjadi penyuluhan kepedulian lingkungan oleh mahasiswa dan dosen ke Mahasiswa jurusan lain (S1 Pendidikan Matematika). Instrumen penelitian adalah self evaluation, pretest dan posttest. Data self evaluation dianalisis dengan deskrriptif. Sedangkan data pretest dan posttest dianalisis menggunakan statistik inferensial parametrik melalui uji satu sampel t-tes dengan bantuan SPSS 16.0 for Windows. Hasil analisis data menunjukkan bahwa ada pengaruh Pelatihan Dasar pada karakter karakter kesadaran lingkungan siswa dengan nilai signifikansi pengujian satu sampel t-test dengan bantuan SPSS 16.0 for Windows sebesar 0.000. Seluruh kegiatan bernuansa nilai dasar, peran, dan kedudukan ASN dalam NKRI.
\end{abstract}

Kata Kunci: pelatihan dasar, karakter, kepedulian lingkungan 


\section{PENDAHULUAN}

Berdasarkan UU No 5 Tahun 2014 tentang Aparatur Sipil Negara pasal 64 ayat 2 tertulis bahwa Instansi Pemerintah wajib memberikan pendidikan dan pelatihan kepada calon PNS sebagaimana dimaksud pada ayat (1) selama masa percobaan. Lebih jelas pasal 65 ayat 1 tertulis bahwa Calon PNS yang diangkat menjadi PNS harus memenuhi persyaratan: a. lulus pendidikan dan pelatihan; dan b. sehat jasmani dan rohani. Dua pasal di atas menjelaskan dasar hukum dan pentingnya Pelatihan Dasar CPNS.

Pelatihan bertujuan meningkatkan kemampuan peserta dalam Knowledge, Skill dan Attitude atau dalam pendidikan secara umum masuk dalam ranah kognitif, psikomotorik, dan afektif. Ranah yang telah dirumuskan Bloom dan disempurnakan (Anderson \& Krathwohl, 2015) tersebut dapat dicapai melalui berbagai proses pembelajaran terstuktur (internalisasi) dan praktek (habituasi dan aktualisasi) seperti yang diterapkan di Balai Besar Pelatihan Kesehatan (BBPK) Makassar. Salah satu proses yang digunakan untuk mencapai kompetensi tersebut melalui proses aktualisasi di unit kerja masing-masing.

Format Pelatihan Dasar tahun 2018 berbeda dengan pelatihan Dasar sebelumnya. Pada tahun 2016 dengan nama Pendidikan dan Pelatihan Prajabatan CPNS telah dilaksanakan proses on campus dan off campus, tetapi kegiatan aktualisasi tanpa ditentukan tema tertentu. Hal ini berarti seluruh aktifitas dapat dilakukan dan dilaporkan dalam aktualisasi. Pada tahun 2018 aktualisasi bersifat memecahkan core issue atau permasalahan (tema) yang diangkat. Hal ini aktifitas harus terkait dengan tema atau isu yang dipilih peserta. Kelebihan on campus dengan banyak media dan model adalah siswa lebih semangat untuk belajar. Siswa mudah menerima isi materi pembelajaran. Kelebihan pembelajan off campus, siswa dapat mengkombinasikan pembelajaran yang di dapat di dalam kelas. Siswa dapat menerapkan materi pada kehidupan sekitar atau pembelajaran bermakna. Menurut (Harianto et al., 2019) belajar di luar kelas bermakna, dalam arti terdapat proses dikaitkannya informasi baru pada konsep-konsep yang relevan dalam struktur kognitif seseorang. Menurut (Prasetya, 2014) proses pembelajaran di luar kelas dapat memberikan pengalaman langsung sehingga pelajaran semakin kongkrit dan nyata yang berarti pembelajaran semakin bermakna.

Pembaharuan pola Pelatihan Dasar ini bertujuan untuk mengaktualisasikan nilai-nilai dasar PNS serta Kedudukan dan Peran PNS dalam NKRI diharapkan menghasilkan PNS yang professional serta SMART ASN dalam menghadapi revolusi 4.0. Pola ini mengaktualisasikan nilai-nilai dasar PNS serta Kedudukan dan Peran PNS dalam NKRI dengan fokus dalam core issue terkait peningkatan karakter kepedulian lingkungan mahasiswa. Tujuan utama aktualisasi untuk menanamkan nilai-nilai dasar PNS serta Kedudukan dan Peran PNS dalam NKRI serta mengimplementasikan untuk meningkatkan mutu pelayanan saat pelatihan dan setelah pelatihan.

Kelebihan-kelebihan pola Pelatihan Dasar menunjukkan bahwa metode ini penting untuk diterapkan untuk keberhasilan pelatihan sesuai amanat Undang-Undang. Kurikulum Latsar CPNS Kemenristek Dikti di BBPK Makassar menjadwalkan peserta untuk melaksanakan aktualisasi. Aktualisasi menghabituasikan nilainilai dasar PNS serta kedudukan dan peran PNS dalam NKRI. Menurut (Utomo et al., 2017) agenda habituasi bertujuan agar peserta mendapatkan pemahaman tentang aktualisasi baik dalam perencanaan maupun pelaksanaannya.

Nilai-nilai dasar ASN terdiri dari lima yang disingkat ANEKA. ANEKA merupakan akronim dari Akuntabilitas, Nasionalisme, Etika Publik, Komitmen Mutu, dan Anti Korupsi. Kedudukan dan peran ASN dalam NKRI terdiri dari tiga, yaitu Manajemen ASN, Whole of Government dan Pelayanan Publik. Kedelapan nilai di atas tercermin dalam kegiatan dalam pemecahan isu dalam kegiatan pelatihan dasar CPNS Kementristek Dikti 2019.

Lingkungan merupakan komponen penting dalam hidup manusia. Pendidikan Geografi dokumen kurikulum program studi tahun 2017 di dalamnya terdapat mata kuliah yang terkait dengan lingkungan seperti: Ekologi dan Ilmu Lingkungan (Semester II) dan Analisis Dampak Lingkungan (semester VII). Mahasiswa Pendidikan Geografi seharusnya memiliki karakter kepedulian lingkungan (environtment awareness) yang tinggi karena sudah mendapatkan mata kuliah yang terkait dengan lingkungan hidup. Pada kenyataannya mahasiswa semester IV (Angkatan 2016) tahun akademik 2017-2018 banyak mempraktekkan perilaku yang tidak mencerminkan kepedulian lingkungan, seperti: membuang sampah pribadi sembarangan di laci meja, lantai ruang kelas, dan di lingkungan kampus; tidak ada kesadaran mematikan lampu dan kipas angin di dalam kelas setelah pelaksanaan perkuliahan; dan belum ada kegiatan-kegiatan yang mencerminkan kesadaran lingkungan 
diantaranya menanam pohon bersama, membersihkan sampah bersama. Menurut (Sejati et al., 2016) permasalahan lingkungan hidup khususnya karst setelah diamati siswa melalui outdoor study diakibatkan dampak negatif penambangan tanpa ijin, partisipasi masyarakat dapat membantu beban pemerintah dalam penanggulangan permasalahan tersebut seperti yang terjadi di dusun Karan sebagai bukit yang lestari.

Kepedulian lingkungan sejalan dengan program go green dengan prinsip: recycle misalnya pembuangan air di AC ditampung untuk disiramkan di pohon, reduce misalnya print tugas mahasiswa depan belakang, reuse misalnya sampah organik diolah menjadi pupuk kompos. Kurangnya kepedulian lingkungan perlu didukung oleh fasilitas pendukung oleh Universitas, seperti: tanda dilarang menginjak taman/rumput, nama latin jenis-jenis flora di kampus, fasilitas kegiatan peringatan hari bumi 22 April, dan peringatan mematikan peralatan listrik di kelas. Kegiatan yang menguatkan perkuliahan lingkungan juga belum dilaksanakan oleh dosen di S1 Pendidikan Geografi FKIP USN Kolaka. Menurut (Chen \& Chiu, 2016) efektivitas pelaksanaan kegiatan peduli lingkungan seperti go green akan lebih baik jika menggunakan berbagai produk. Menurut (Rusuli et al., 2016) penerapan go green dapat memproteksi lingkungan dan berhubungan signifikan dengan karakter yang tertuang dalam pendidikan dan aksi legal.

Sumber isu berdasarkan realitas di ruang perkuliahan saat proses pembelajaran mata kuliah Geografi Regional Dunia dan Antropologi semester genap tahun akademik 2017-2018, serta observasi langsung aktivitas mahasiswa setelah perkuliahan saat masih di lingkungan kampus USN.

Dampak jika isu tidak segera dipecahkan, mahasiswa Pendidikan Geografi hendaknya menjadi pioner atau tunas dalam menjaga dan melestarikan lingkungan hidup baik di dalam, kelas, kampus, maupun di lingkungan tempat tinggal masing-masing mahasiswa. Setelah meningkat kepedulian mahasiswa diharapkan dapat mempengaruhi atau menularkan karakter tersebut di lingkup keluarga mereka, dan masyarakat di tempat tinggal mereka. Hal ini selaras dengan salah satu aspek sikap dalam (Permenristekdikti Nomor 44 Tahun 2015 tentang Standar Nasional Pendidikan Tinggi LLDIKTI Wilayah XIII, n.d.), yaitu bekerja sama dan memiliki kepekaan sosial serta kepedulian terhadap masyarakat dan lingkungan.
Apabila tidak dilakukan, maka kerusakan lingkungan akan berpotensi semakin parah dari sekarang. Kepedulian lingkungan juga dilandasi oleh regulasi pemerintah, yaitu gerakan hemat energi dan go green. Menurut (Hamzah, 2016) pertambangan nikel di Pomalaa, Kolaka menyebabkan rusaknya vegetasi tutupan lahan, lapisan tanah atas, dan meningkatnya sedimentasi material tanah dan batuan menuju pantai yang berakibat ikan di sekitar pantai berkurang. Menurut (Musyahada, 2011) terdapat perubahan fungsi lahan dari hutan menjadi perkebunan kakao dan cengkeh sehingga vegetasi alami berkurang serta masyarakat terkena dampak bencana banjir serta tanah longsor.

\section{METODOLOGI}

Jenis penelitian ini adalah pra-eksperimen dengan subjek penelitian mahasiswa S1 Pendidikan Geografi, Universitas Sembilanbelas November Kolaka pada semester $V$ tahun akademik 2018-2019 dengan total 20. Pemilihan subjek penelitian didasarkan pada pengambilan kelas ekologi dan lingkungan yang sudah diambil saat semester III tahun akademik 2017-2018. Instrumen penelitian menggunakan 12 item pertanyaan esai dengan rincian skor 6 pertanyaan 5 , skor 4 pertanyaan 10, dan skor 2 pertanyaan 15 . Pedoman penilaian menggunakan kriteria jawaban sesuai dengan skala Likert yang dibagi menjadi 5 rentang. Instrumen ini divalidasi oleh tim dua ahli yang terkait dengan lingkungan. Penentuan issue menggunakan analisis urgency, serious, dan growth atau USC sesuai panduan (Utomo et al., 2017).

Strategi penyelesaian core issue ini dengan cara yang diadopsi dari Pelatihan Dasar CPNS, yaitu on campus dan off campus. Terdapat enam kegiatan, tiga kegiatan on campus dan tiga kegiatan off campus. Kegiatan on campus meliputi: pertama, melaksanakan penyuluhan peduli lingkungan kepada mahasiswa. Kedua, penerapan pakta integritas peduli lingkungan. Ketiga pelatihan SIC kajian lingkungan. Kegiatan off campus meliputi: pertama, penanaman Pohon di lingkungan kampus. Kedua, pembersihan selokan di lingkungan kampus. Ketiga, kegiatan penyuluhan dan sosialisasi ke ke mahasiswa program studi lain.

Data pretest dan posttest yang menunjukkan kepedulian siswa terhadap lingkungan. Perbedaan antara pretest dan posttest diperoleh oleh gainscore yang kemudian dianalisis menggunakan satu sampel t-test dengan bantuan SPSS 16.0 untuk Windows. 
Sebelum diuji untuk hipotesis, gainscore diuji normalitas dengan satu sampel Kolmogorov Smirnov.

\section{HASIL DAN PEMBAHASAN}

Gainscore berdasarkan tes prasyarat analisis (normalitas) dengan one sample Kolmogorov Smirnov termasuk berdistibusi normal yaitu nilai asymp sig (2-tailed) sebesar 0,832 . Nilai sig (2-tailed) $>0,05$ sehingga data gainscore terdistribusi normal. Berdasarkan analisis statistik inferensial dengan one sample ttest dengan bantuan SPSS 16.0 for Windows didapatkan nilai signifiansi 0,000. Nilai sig (2tailed) $<0,05$, hal ini menunjukkan penerapan metode latsar (on campus dan off campus) berpengaruh terhadap karakter peduli lingkungan mahasiswa. Pada kegiatan terdapat nilai dasar, kedudukan dan peran ASN dalam NKRI. Berikut Tabel hasil pretest, posttest, dan gainscore.

Tabel 1. Pretest, Posttest, dan Gainscore Aktualisasi Mahasiswa Pendidikan Geografi

\begin{tabular}{lccc}
\hline Mahasiswa & Pretest & Posttest & Gainscore \\
\hline Sampel Mahasiswa 1 & 59 & 71 & 12 \\
Sampel Mahasiswa 2 & 42 & 61 & 19 \\
Sampel Mahasiswa 3 & 58 & 77 & 19 \\
Sampel Mahasiswa 4 & 57 & 77 & 20 \\
Sampel Mahasiswa 5 & 43 & 69 & 26 \\
Sampel Mahasiswa 6 & 44 & 67 & 23 \\
Sampel Mahasiswa 7 & 44 & 69 & 25 \\
Sampel Mahasiswa 8 & 45 & 77 & 32 \\
Sampel Mahasiswa 9 & 48 & 76 & 28 \\
Sampel Mahasiswa 10 & 38 & 65 & 27 \\
Sampel Mahasiswa 11 & 51 & 72 & 21 \\
Sampel Mahasiswa 12 & 33 & 76 & 43 \\
Sampel Mahasiswa 13 & 32 & 61 & 39 \\
Sampel Mahasiswa 14 & 29 & 89 & 32 \\
Sampel Mahasiswa 15 & 41 & 69 & 48 \\
Sampel Mahasiswa 16 & 44 & 76 & 25 \\
Sampel Mahasiswa 17 & 47 & 79 & 29 \\
Sampel Mahasiswa 18 & 56 & 76 & 23 \\
Sampel Mahasiswa 19 & 48 & & 30 \\
Sampel Mahasiswa 20 & 46 & & \\
\hline
\end{tabular}

Berikut hasil aktualisasi pemecahan core issue peningkatan kepedulian lingkungan mahasiswa. Kegiatan I: Melaksanakan penyuluhan peduli lingkungan kepada mahasiswa. Sub kegiatan pertama, koordinasi dengan atasan langsung (PLT kaprodi) dan atasan dari atasan langsung (Dekan FKIP USN) terkait pelaksanaan kegiatan. Nilai yang terkandung didalam kegiatan koordinasi adalah whole of government, manajemen ASN, akuntabilitas, pelayanan publik, dan etika publik. Menurut (Suwarno \& Sejati, 2017) whole of government terdiri atas koordinasi, kolaborasi, inovasi dan pelayanan publik. Berikut matrik kegiatan aktualisasi.

Tabel 2. Matrik Aktualisasi

\begin{tabular}{|c|c|c|}
\hline No & Kegiatan & Pelaksanaan \\
\hline 1 & $\begin{array}{l}\text { Melaksanakan penyuluhan peduli lingkungan kepada } \\
\text { mahasiswa S1 Pendidikan Geografi, FKIP, USN }\end{array}$ & $\begin{array}{l}\text { Agustus Minggu ke-3 s.d September } \\
\text { Minggu ke-3 } 2018\end{array}$ \\
\hline 2 & Penerapan pakta integritas peduli lingkungan & $\begin{array}{l}\text { September Minggu ke-1 s.d November } \\
\text { Minggu ke-3 } 2018\end{array}$ \\
\hline 3 & Pelatihan SIG kajian lingkungan & $\begin{array}{l}\text { September Minggu ke-2 s.d Oktober } \\
\text { Minggu ke-2 } 2018\end{array}$ \\
\hline 4 & Penanaman Pohon di lingkungan kampus USN Kolaka & Oktober Minggu ke-2 s.d 32018 \\
\hline 5 & Pembersihan Selokan di lingkungan kampus USN Kolaka & Oktober Minggu ke-4 2018 \\
\hline 6 & $\begin{array}{l}\text { Kegiatan penyuluhan dan sosialisasi ke masyarakat } \\
\text { diadaptasi menjadi penyuluhan kepedulian lingkungan } \\
\text { oleh mahasiswa dan dosen ke Mahasiswa jurusan lain ( } S 1 \\
\text { Pendidikan Matematika }\end{array}$ & November Minggu ke-1 s.d 32018 \\
\hline
\end{tabular}


Koordinasi (whole of government) dimulai dari atasan langsung yaitu PLT Kaprodi, kemudian ke struktur (manajemen ASN) yang lebih tinggi yaitu atasan dari atasan langsung (Wakil Dekan II) dengan mendiskusikan serta meminta persetujuan terkait rencana aktualisasi yang akan dilakukan dengan memberikan rancangan aktualisasi supaya pemimpin mendapat kejelasan (akuntabilitas). Pelaksanaan koordinasi mempraktekkan etiket (pelayanan publik) dalam memberikan salam, berjabat tangan yang baik, dan menggunakan bahasa yang santun (etika publik) sehingga tercapai pelayanan (pelayanan publik) kepada mahasiswa yang prima. Tempat koordinasi dengan PLT Kaprodi di ruang 5 Prodi, Rektorat, USN, sedangkan Wakil Dekan II di ruang Dekanat FKIP. Menurut (Fatimah \& Irawati, 2017) manajemen ASN meliputi beberapa hal salah satunya pangkat dan jabatan.

Sub kegiatan kedua penyusunan rencana pelaksanaan penyuluhan. Nilai yang terkandung didalam kegiatan ini adalah manajemen ASN, etika publik, komitmen mutu, pelayanan publik. Perencanaan (manajemen ASN) dibuat sesuai dengan format kegiatan pada umumnya berdasar keilmuan (etika publik) Geografi Lingkungan. Rencana kegiatan dimulai dengan pembuatan soal pretest-posttest yang dikonsultasikan dengan mentor dan coach sekaligus sebagai validator soal, waktu dan tempat, pembuatan materi, metode pembelajaran yang diadaptasi/adapt (komitmen mutu) dari widyaiswara BBPK Makassar. Selanjutnya pada tanggal 7 September 2018 di ruang A.3 FKIP, mahasiswa diberi penjelasan pelaksaan rangkaian aktualisasi dengan etiket (pelayanan publik) saat penyampaian agar mahasiswa mendapatkan kejelasan (akuntabilitas). Menurut (Kumorotomo et al., 2015) indikator etika publik tertulis pada UU No 5 Tahun 2014 pasal 4 diantaranya membuat keputusan berdasarkan prinsip keahlian.

Sub kegiatan ketiga, pelaksanaan kegiatan penyuluhan peduli lingkungan. Nilai yang terkandung didalam kegiatan ini adalah akuntabilitas, nasionalisme, etika publik, anti korupsi, pelayanan publik. Diawali dengan pembuatan komitmen untuk melatih integritas (akuntabilitas) mahasiswa berlaku selama pelaksanaan, terkait dengan disiplin dalam kedatangan, aktif saat proses aktualisasi, dan tidak terlambat, serta tidak gaduh/berbicara sesuatu diluar kegiatan. Pelaksanaan pretest dilaksanakan pada 9 September 2018 di ruang
A.10 FKIP dengan jujur (nasionalisme, etika publik, dan anti korupsi) tanpa mencontek. Jujur menerapkan pancasila sila pertama, Ketuhanan yang Maha Esa karena jujur dipertanggung jawabkan kepada Tuhan. Jujur termasuk dalam salah satu nilai dasar etika publik dalam (Republik Indonesia, 2014) pasal 4 poin ke 10. Jujur juga salah satu indikator anti korupsi, dengan tidak mencontek saat ujian, merupakan cikal bakal untuk tidak korupsi.

Sub kegiatan keempat, laporan kepada atasan langsung (PLT kaprodi) dan atasan dari atasan langsung (Dekan FKIP USN). Nilai yang terkandung didalam kegiatan ini adalah manajemen ASN, whole of government, akuntabilitas, nasionalisme, etika publik, anti korupsi.

Pelaporan (manajemen ASN) kepada atasan langsung dan atasan dari atasan langsung secara lisan (etika publik) tentang kegiatan pertama dengan baik menunjukkan koordinasi (WoG) dan tanggung jawab (akuntabilitas, nasionalisme, etika publik, anti korupsi) beserta tanda tangan sertifikat penyuluhan untuk instruktur. Tanggung jawab dalam pandangan akuntabilitas secara personal/responsibilitas perseorangan bercirikan: adanya pengakuan terhadap tindakan yang telah diputuskan dan tindakan yang dilakukan dalam hal ini kegiatan pertama, adanya pengakuan terhadap etika dalam pengambilan keputusan khususnya dalam proses pertanggung jawaban secara lisan, dan adanya keterlibatan konstituen yang tepat dalam keputusan dalam hal ini pimpinan dan mahasiswa. Tanggung jawab versi nasionalisme mempraktekkan sila pertama, Ketuhanan yang Maha Esa, Pertanggung jawaban di hadapan manusia dan Tuhan. Tanggung jawab dalam etika publik masuk dalam nilai dasar etika publik dalam (Republik Indonesia, 2014) pasal 4 poin ke 8. Tanggung jawab dalam anti korupsi dalam hal ini, merupakan nilai yang tidak dipegang koruptor. Koruptor sudah pasti tidak mampu bertanggung jawab terhadap kegiatan yang nyata bertentangan dengan UU.

Kegiatan II: Penandatanganan dan deklarasi pakta integritas peduli lingkungan. Sub kegiatan pertama, merancang isi pakta integritas. Nilai yang terkandung didalam kegiatan ini adalah akuntabilitas, nasionalisme, etika publik, dan anti korupsi. Pelaksanaan tugas dengan penuh tanggung jawab (akuntabilitas, nasionalisme, etika publik, dan anti korupsi) dengan menyusun isi pakta integritas yang bernuansa kepedulian lingkungan yang akan diterapkan mahasiswa subjek aktualisasi. Menurut (KPK, 2015) salah 
satu indikator anti korupsi adalah tanggung jawab.

Sub kegiatan kedua, koordinasi dengan PLT kaprodi terkait pelaksanaan pakta integritas. Nilai yang terkandung sama dengan kegiatan I. Sub kegiatan ketiga, penandatanganan dan deklarasi pakta integritas. Nilai yang terkandung didalam kegiatan ini adalah akuntabilitas, komitmen mutu, dan pelayanan publik. Salah satu bentuk integritas (akuntabilitas) untuk menerapkan UU yang berlaku. Illegal logging dan sejenisnya merupakan tindakan melanggar hukum. Dengan belajar hal kecil, menjauhi hal besar tersebut. Membuang sampah sembarangan sampai saat ini belum masuk dalam sanksi hukum, tetapi sudah beberapa tempat yang diberlakukan peraturan daerah dan mengikat sanksi denda. Pakta integritas merupakan salah satu bentuk inovasi (komitmen mutu) dalam hal ini pelayanan yang berbeda dan murah, artinya menjadikan kegiatan perkuliahan lebih mudah dan murah (pelayanan publik). Murah dalam hal penggunaan kertas bolak-balik dan upaya pengurangan penggunaan kertas (Kusumasari et al., 2015; Purwanto et al., 2017; Yuniarsih \& Taufiq, 2016).

Sub kegiatan keempat, pelaksanaan pakta integritas. Nilai yang terkandung didalam kegiatan ini adalah akuntabilitas, nasionalisme, etika publik, anti korupsi, whole of government. Tanggung jawab (akuntabilitas, nasionalisme, etika publik, anti korupsi) terhadap hasil kesepakatan baik dari pihak pertama maupun pihak kedua menjadi hal penting. Tanggung jawab merupakan bentuk pertanggung jawaban personal dalam akuntabilitas, pertanggung jawaban pada manusia dan tuhan pada Nasionalisme pancasila sila pertama, salah satu poin nilai dasar etika publik dalam UU ASN, dan nilai yang menjauhkan diri dari korupsi. Nilai integritas (akuntabilitas) juga terkandung dalam penerapan pakta integritas, sesuai dengan namanya yaitu taat pada peraturan yang selaras dengan perundang-undangan yang berlaku. Pihak pertama dan pihak kedua harus ada unsur percaya (akuntabilitas) satu dengan lainnya, tetapi pihak pertama juga tetap mengawasi pelaksanaan utamanya saat perkuliahan. Waktu pelaksanaan cukup lama, sehingga perlu konsistensi (akuntabilitas) dari pihak-pihak yang terlibat, dalah hal ini dosen pelaksana aktualisasi dan mahasiswa subjek aktualisasi. Pelaksanaan do'a membuat suasana lebih religius dan amanah (nasionalisme), serta melatih koordinasi (whole of government) mahasiswa dengan dosen.
Kegiatan III: Pelatihan Sistem Informasi Geografi kajian lingkungan hutan bagi mahasiswa. Sub kegiatan pertama, koordinasi dengan PLT kaprodi dan Dekan FKIP USN terkait pelaksanaan kegiatan SIC kajian lingkungan. Nilai yang terkandung didalam kegiatan ini sama dengan kegiatan I dan II.

Sub kegiatan kedua, pembuatan dan pengumpulan proposal kegiatan pelatihan SIC kajian lingkungan. Nilai yang terkandung didalam kegiatan ini adalah manajemen ASN, whole of governemnt, pelayanan publik. Proposal (manajemen ASN) berisi ijin (whole of governemnt) pelaksa'naan dan legalitas penerbitan sertifikat untuk instruktur dan mahasiswa (pelayanan publik). Berisi juga metode, materi, waktu, dan tempat pelatihan untuk meningkatkan penguasaan teknologi GIS fokus lingkungan.

Sub kegiatan ketiga, pelaksanaan kegiatan pelatihan SIC kajian lingkungan. Nilai yang terkandung didalam kegiatan ini adalah akuntabilitas, komitmen mutu, pelayanan publik, whole of government. Diawali pembuatan komitmen untuk melatih integritas (akuntabilitas) mahasiswa mulai latihan pemetaan dari tahap georeferensing, digitasi, editing, labelling, dan layout pelaksanaan kegiatan teknologi pemetaan GIS (komitmen mutu). Pemetaan fokus kawasan hutan dan dikaitkan dengan kondisi sebenarnya supaya mahasiswa mengerti keadaan lingkungan hutan di suatu wilayah. Pelaksanaan dengan etiket (pelayanan publik) yang baik, penutup disertai penjelasan (whole of government) rangkaian kegiatan yang terkait dengan kegiatan pertama, kedua, dan ketiga supaya mahasiswa jelas (akuntabilitas), yaitu kegiatan penanaman pohon. Menurut Rozpondek, Wanclslewicz, dan Kocprzak (2016) kenampakan lingkungan akan lebih bagus dengan GIS karena spasial mudah dipahami.

Sub kegiatan keempat, laporan pelaksanaan kegiatan pelatihan SIC kajian lingkungan kepada Dekan FKIP USN. Nilai yang terkandung didalam kegiatan ini sama dengan pelaporan di kegiatan $\mathrm{I}$.

Kegiatan IV: Penanaman pohon di lingkungan Kampus USN Kolaka. Sub kegiatan pertama, koordinasi dengan PLT kaprodi, Dekan FKIP USN. Nilai yang terkandung didalam kegiatan ini adalah whole of government, manajemen ASN, akuntabilitas, pelayanan publik, etika publik. Koordinasi (whole of government) dengan mendiskusikan serta meminta persetujuan terkait kegiatan penanaman supaya pimpinan (manajemen ASN) mendapat kejelasan (akuntabilitas) dan 
menggunakan etiket (pelayanan publik) memberikan salam dan jabat tangan yang baik serta yang bahasa yang santun (etika publik) sehingga tercapai pelayanan di kampus bertema peduli lingkungan. Pimpinan menyetujui untuk menanam di samping gedung FKIP karena termasuk dalam lahan yang tidak tertanami (kosong) dan ditumbuhi rumput liar. Penanaman tidak dapat dalam bentuk pohon besar karena lahan di Kampus USN Kolaka sudah penuh dengan pohon pelindung. Tanaman taman dan tanaman kecil yang dapat ditanam di lokasi tersebut. Adapun Kampus Baru USN Kolaka masih dalam musim kemarau dan habis mengalami kebakaran ilalang yang menghanguskan seluruh vegetasi/tanaman termasuk mengeringkan tanah. Menurut Sejati, Amaluddin, Hidayati, \& Kasmiati (2017), kegiatan perencanaan meliputi area selection merupakan langkah penting pembelajaran outdoor.

Sub kegiatan kedua, pelaksanaan kegiatan penanaman pohon. Nilai yang terkandung didalam kegiatan ini adalah nasionalisme, whole of government, pelayanan publik, etika publik. Kegiatan dilaksanakan dengan menanam pohon bersama (nasionalisme) sesuai tempat yang disepakati (whole of government) dengan pimpinan. Dimulai dengan membersihkan rumput dan sampah bersamasama gotong royong mencerminkan sila ketiga. Tanah digemburkan terlebih dahulu dan melaksanakan penanaman serta penyiraman. Mahasiswa dan dosen (etika publik) melakukan interaksi langsung di lingkungan, harus menunjukkan etika (etika publik) yang baik. Menurut (Gunarsa \& Ningsih, 2014) materi di dalam kelas dan luar kelas diterima secara bersama-sama dan saling mengisi, setiap kali anak menyesuaikan diri dengan lingkungan. Menurut (Fayanto et al., 2019) outdoor learning dalam bentuk pembelajaran luar kelas untuk melihat peristiwa langsung di lapangan dengan tujuan mengakrabkan siswa dengan lingkungannya.

Sub kegiatan ketiga, laporan kepada atasan langsung (PLT kaprodi), atasan dari atasan langsung (Dekan FKIP USN). Nilai yang terkandung didalam kegiatan ini adalah manajemen ASN, etika publik, whole of government, akuntabilitas, nasionalisme, etika publik, anti korupsi. Pelaporan (manajemen ASN) secara lisan (etika publik) kegiatan menunjukkan koordinasi (whole of government) dan tanggung jawab (akuntabilitas, nasionalisme, etika publik, anti korupsi). Pimpinan mengapresiasi kegiatan penanaman pohon karena berperan dalam membersihkan lingkungan FKIP dan menambah keindahan melalui tanaman/bunga yang ditanam. Menurut (Latief et al., 2015) nilai nasionalisme ada di tanggung jawab sebagai representasi Pancasila sila pertama.

Kegiatan V: Pembersihan selokan di lingkungan Kampus USN Kolaka. Sub kegiatan pertama, koordinasi dengan PLT kaprodi, Dekan FKIP USN terkait pelaksanaan kegiatan pembersihan selokan. Nilai yang terkandung didalam kegiatan ini adalah whole of government, manajemen ASN, akuntabilitas, pelayanan publik, etika publik. Koordinasi (whole of government) dengan mendiskusikan serta meminta persetujuan terkait kegiatan penanaman supaya pimpinan (manajemen ASN) mendapat kejelasan (akuntabilitas) dan menggunakan etiket (pelayanan publik) memberikan salam dan jabat tangan yang baik serta yang bahasa yang santun (etika publik) sehingga tercapai pelayanan di kampus bertema peduli lingkungan. Pembersihan selokan disepakati sekitar kantor dan ruang perkuliahan FKIP USN Kolaka.

Sub kegiatan kedua, pelaksanaan kegiatan pembersihan selokan. Nilai yang terkandung didalam kegiatan ini adalah nasionalisme, whole of government, pelayanan publik, etika publik. Kegiatan dilaksanakan dengan membersihkan sampah di selokan terlebih dahulu, kemudian mengeruk sedimen di selokan bersama (nasionalisme) sesuai tempat yang disepakati (whole of government) dengan pimpinan (sekitar FKIP). Gotong royong dan rela berkorban waktu, biaya, serta tenaga memupuk rasa nasinalisme Pancasila sila ke-tiga. Mahasiswa dan dosen (pelayanan publik) melakukan interaksi langsung di lingkungan, harus menunjukkan etika (etika publik) yang baik. Mahasiswa juga memahami erosi serta sedimentasi. Menurut (Özdilek et al., 2011) pembelajaran outdoor environtmental education dapat meningkatkan kesadaran dan sikap positif terhadap lingkungan. Menurut (Sudjana \& Rifai, 2015) belajar di luar kelas siswa dapat memahami dan menghayati aspekaspek kehidupan yang ada di lingkungannya, sehingga dapat membentuk pribadi yang tidak asing dengan kehidupan membentuk sekitarnya, serta dapat memupuk cinta lingkungan.

Sub kegiatan ketiga, laporan kepada atasan langsung (PLT kaprodi), atasan dari atasan langsung (Dekan FKIP USN). Nilai yang terkandung didalam kegiatan ini sama dengan kegiatan laporan sebelumnya. Hal ini 
ditemukan bahwa drainase FKIP merupakan jalur keluar air menuju selokan yang lebih besar di belakang kantor FKIP yang mengalir ke luar kampus (persawahan). Drainase di dalam kampus tidak terhubung ke selokan besar sehingga air diam/macet di tempat dan menyebabkan banjir. Air mengalir sedikit ke selokan besar melalui badan jalan yang sedikit menanjak, sehingga terjadi genangan yang cukup lama. Pimpinan mencatat masukan yang ditemukan dalam kegiatan akutualisasi ini.

Kegiatan VI: Melaksanakan penyuluhan peduli lingkungan oleh mahasiswa dan dosen S1 Pendidikan Geografi, FKIP, USN kepada Mahasiswa selain jurusan S1 Pendidikan Geografi (Pendidikan Matematika). Sub kegiatan pertama, koordinasi dengan PLT kaprodi, Dekan FKIP USN, dan Kaprodi Pendidikan Matematika terkait pelaksanaan kegiatan penyuluhan lingkungan. Nilai yang terkandung didalam kegiatan ini adalah whole of government, manajemen ASN, akuntabilitas, pelayanan publik, etika publik. Koordinasi (whole of government) dengan mendiskusikan serta meminta persetujuan terkait kegiatan penyuluhan supaya pimpinan (manajemen ASN) mendapat kejelasan (akuntabilitas) dan menggunakan etiket (pelayanan publik) memberikan salam dan jabat tangan yang baik serta yang bahasa yang santun (etika publik) sehingga tercapai pelayanan di kampus bertema peduli lingkungan. Ketua Program Studi Pendidikan Matematika setuju untuk diadakan penyuluhan oleh mahasiswa Pendidikan Geografi ke mahasiswa Pendidikan Matematika merupakan bentuk Kolaborasi. Wakil Dekan II dan PLT Kaprodi Pendidikan Geografi juga mendukung kegiatan tersebut.

Sub kegiatan kedua, pelaksanaan kegiatan penyuluhan lingkungan. Kegiatan dilaksanakan pada tanggal 9 November 2018 dengan melakukan penyuluhan di ruangan FKIP sesuai kesepakatan (whole of government). Mahasiswa dan dosen (pelayanan publik) melakukan interaksi langsung di lingkungan, harus menunjukkan etika (etika publik) yang baik. Pasca kegiatan mahasiswa mengerjakan posttest pada tanggal 10 November 2018 dengan jujur (nasionalisme, etika publik, anti korupsi). Mahasiswa menjelaskan apa yang didapatkan selama internalisasi (agenda 1-3) dan habituasi (agenda 4-5). Agenda 6 merupakan bentuk off campus terakhir dengan menyebarkan pengetahuan kepada lingkungan sekitar (dalam hal ini mahasiswa di lingkup FKIP dengan sampel Pendidikan Matematika). Posttenst digunakan untuk mengukur keberhasilan pelaksanaan kegiatan. Menurut
(Sumarmi \& Amirudin, 2014) salah satu cara mengendalikan kerusakan lingkungan dengan pembinaan etika pada masyarakat (termasuk siswa) sehingga terjadi perubahan sikap dan perilaku.

Sub kegiatan ketiga, laporan kegiatan penyuluhan lingkungan kepada PLT Kaprodi Pendidikan Geografi, kaprodi pendidikan matematika, dan Dekan FKIP USN. Pelaporan (manajemen ASN) secara lisan (etika publik) kegiatan menunjukkan koordinasi (whole of government) dan tanggung jawab (akuntabilitas, nasionalisme, etika publik, anti korupsi) beserta tanda tangan sertifikat pelatihan untuk instruktur. Pelaporan kepada Kaprodi Pendidikan Matematika khusus agenda 6. Laporan kepada Wakil Dekan II dan PLT Kaprodi Pendidikan Geografi untuk seluruh agenda termasuk penandatanganan sertifikat terkait, sekaligus melaporkan bahwa seluruh agenda selesai dilaksanakan. Kegiatan pelaporan kepada struktur yang lebih tinggi dengan proses kenaikan pangkat sesuai ( $P P$ No 12 Tahun 2002, n.d.)

\section{KESIMPULAN}

Terdapat pengaruh antara metode Pelatihan Dasar terhadap karakter kepedulian lingkungan hidup mahasiswa dengan nilai signifikansi 0,000. Seluruh kegiatan aktualisasi bernuansa nilai-nilai dasar ASN yaitu ankuntabilitas, nasionalisme, etika publik, komitmen mutu, dan anti korupsi. Seluruh kegiatan aktualisasi bernuansa kedudukan dan peran ASN dalam NKRI yaitu manajemen ASN, whole of government, dan pelayanan publik.

\section{DAFTAR PUSTAKA}

Anderson, L. W., \& Krathwohl, D. R. (2015). Kerangka Landasan untuk Pembelajaran, Pengajaran, dan Asesmen Revisi Taksonomi Pendidikan Bloom (A. Priantoro (Ed.)). Pustaka Pelajar.

Chen, M. Y., \& Chiu, C. I. (2016). Go green: How to influence the perceived effectiveness of a green product? International Journal of Advertising, 35(4), 622-641. https://doi.org/10.1080/02650487.2015.1 105647

Fatimah, E., \& Irawati, E. (2017). Modul Pelatihan Dasar Calon PNS "Manajemen ASN.” In Lembaga Administrasi Negara. Lembaga Administrasi Negara RI.

Fayanto, S., Amaluddin, L. O., Rahmat, R., 
Surdin, S., Ramadhan, M. I., Hidayat, D. N., Sejati, A. E., \& Purwana, I. G. (2019). The Effectiveness of Outdoor Learning in Improving Spatial Intelligence. Journal for the Education of Gifted Young Scientists, $7(3)$, 667-680. https://doi.org/10.17478/jegys.613987

Gunarsa, S. ., \& Ningsih, Y. (2014). Psikologi Perkembangan Anak dan Remaja. PT. TBK Gunung Mulia.

Hamzah. (2016). Pengembangan Masyarakat Pesisir di Kawasan Tambang Nikel Pomalaa Sulawesi Tenggara. Bogor. IPB.

Harianto, E., Nursalam, L. O., Ikhsan, F. A., Zakaria, Z., Damhuri, D., \& Sejati, A. E. (2019). THE COMPATIBILITY OF OUTDOOR STUDY APPLICATION OF ENVIRONMENTAL SUBJECT USING PSYCHOLOGICAL THEORIES OF INTELLIGENCE AND MEANINGFUL LEARNING IN SENIOR HIGH SCHOOL. Geosfera Indonesia, 4(2), 201. https://doi.org/10.19184/geosi.v4i2.9903

KPK, T. P. (2015). Anti Korupsi Modul Pendidikan dan Pelatihan Prajabatan Golongan III. Lembaga Administrasi Negara RI.

Kumorotomo, W., Wirapradja, N. R. D., \& Imbaruddin, A. (2015). Etika Publik Modul Pendidikan dan Pelatihan Prajabatan Golongan III. Lembaga Administrasi Negara RI.

Kusumasari, B., Dwiputrianti, S., \& Allo, E. . (2015). Akuntabilitas Modul Pendidikan dan Pelatihan Prajabatan Golongan III. Lembaga Administrasi Negara RI.

Latief, Y., Suryanto, A., \& Muslim, A. A. (2015). Nasionalisme Modul Pendidikan dan Pelatihan Prajabatan Golongan III. Lembaga Administrasi Negara RI.

Musyahada, M. (2011). Arahan Pemanfaatan Ruang di kecamatan Lasusua kabupaten Kolaka Utara.

Özdilek, §̧. Y., Özdilek, H. G., Okur, E., \& Eryaman, M. Y. (2011). Community and Nature As Curriculum : a Case Study of an Outdoor Environmental Education Project *. The International Journal of Educational Researchers, 3(1), 33-45. http://www.eab.org.tr/public/ijer/3/1/sukr an_yalcin_ozdilek.pdf

Permenristekdikti Nomor 44 Tahun 2015 tentang Standar Nasional Pendidikan Tinggi - LLDIKTI Wilayah XIII. (n.d.). Retrieved February 25, 2020, from https://lldikti13.ristekdikti.go.id/2016/01/2 6/standar-nasional-pendidikan-tinggitahun-2015/

PP No 12 Tahun 2002. (n.d.). Retrieved February 25, 2020, from http://hukum.unsrat.ac.id/pp/pp_12_2002 .htm

Prasetya, S. P. (2014). Media Pembelajaran Geografi. Ombak. https://scholar.google.com/scholar?cluster $=2795471514796442042 \& \mathrm{hl}=$ en\&oi $=$ sch olarr

Purwanto, E. A., Tyastiyanti, D., Taufiq, A., \& Novianto, W. (2017). Modul Pelatihan Dasar Calon PNS Pelayanan Publik. Lembaga Administrasi Negara RI.

Republik Indonesia. (2014). Undang-undang Republik Indonesia No.5 tahun 2014 tentang Aparatur Sipil Negara (pp. 1-104).

Rusuli, C., Q, F., N., S., \& M., H. (2016). The Effectiveness of $\mathrm{Go}$ Green Implementation among Society in Kota Bharu, Kelantan. European Journal of Multidisciplinary Studies, $\quad 1(1), \quad 10$. https://doi.org/10.26417/ejms.v1i1.p10-14

Sejati, A. E., Amaluddin, L. O., Hidayati, D. N., \& Kasmiati, S. (2017, May 1). The Effect of Outdoor Study on the Geography Scientific Paper Writing Ability to Construct Student Character in Senior High School. Proceedings of the 5th SEADR (South East Asia Development Research) International Conference 2017 (SEADRIC 2017).

https://doi.org/10.2991/seadric17.2017.22

Sejati, A. E., Sumarmi, S., \& Ruja, I. N. (2016). PENGARUH METODE PEMBELAJARAN OUTDOOR STUDY TERHADAP KEMAMPUAN MENULIS KARYA ILMIAH GEOGRAFI SMA. Jurnal Pendidikan: Teori, Penelitian, Dan Pengembangan, 7(2), 80-86. https://doi.org/10.17977/JP.V112.5804

Sudjana, N., \& Rifai, A. (2015). Media Pengajaran (12th ed.). Sinar Baru Algensindo.

Sumarmi, \& Amirudin, A. (2014). Geografi Lingkungan Berbasis Kearifan Lokal. Aditya Media Publishing.

Suwarno, Y., \& Sejati, T. A. (2017). Modul Pelatihan Dasar Calon PNS "Whole of Government." In Lembaga Administrasi Negara. Lembaga Administrasi Negara RI. https://scholar.google.com/scholar?cluster 
$=7655782595613993771 \& \mathrm{hl}=$ en\&oi $=\mathrm{sch}$

olarr

Utomo, T. W. W., Basseng, \& Purwana, B. H. (2017). Habituasi. Lembaga Administrasi Negara RI.

http://puskan.lan.go.id/files/Modul 2 Habituasi.pdf

Yuniarsih, T., \& Taufiq, M. (2016). Komitmen Mutu Modul Pendidikan dan Pelatihan Prajabatan Golongan III. In Lembaga Administrasi Negara. Lembaga Administrasi Negara RI. 